\title{
PENERIMAAN MASYARAKAT ISLAM DI \\ MALAYSIA TERHADAP AMALAN \\ PERCAMPURAN MAZHAB \\ DALAM ISU-ISU IBADAT
}

\author{
Oleh: \\ Anisah Ab. Ghani* \\ Abd Karim Ali ${ }^{* *}$ \\ Noor Naemah Ab. Rahman ${ }^{* * *}$ \\ Raihanah Hj. Azahari**** \\ Saadan Man ${ }^{* * * * *}$ \\ Luqman Abdullah ${ }^{* * * * * *}$ \\ Shahidra Binti Abdul Khalil*
}

\begin{abstract}
Muslim society in Malaysia acknowledge the existence of Shafi' $i$ madhhab since the spread of Islam in this region. This madhhab had influenced the society's thoughts and practices through the traditional education system, literatures, laws and the local scholars. Basically, Muslim society in Malaysia are bound by the opinion of Shafi' $i$ madhhab as declared in the enactment of the states. Nevertheless, there are rooms for another madhhabs to be selected and practiced in Malaysia if certain issues are related to public interest (maslahah). On the other hand, the use of madhhabs, talfiq and takhayyur have become a polemic among the scholars regarding its necessity and validity. Hence, this article attempts to estimate to what extent the practices of Muslim society in Malaysia in devotion aspect are still bound by the opinions of the Shafi'i madhhab. The related issues that will be discussed are ablution (taharah), prayer, fasting and zakat. To obtain the data needed, questionnaires had been distributed to selected respondents with religious education background from Kelantan, Terengganu, Perlis, Kedah, Johor and Kuala Lumpur. These states represent north, east, south and middle part of Malaysia. Besides that, interview with several informant also had been conducted.
\end{abstract}




\section{PENDAHULUAN}

Mazhab Syafi'i menjadi rujukan utama dalam amalan hukum di Malaysia. Enakmen pentadbiran agama Islam negeri-negeri dengan jelas telah menyebutkan rujukan hukum utama mesti dilakukan kepada pandangan muktamad Syafi' $i$. Secara amalannya juga, tradisi berpegang kepada pandangan hukum Syafi'i dalam urusan ibadat di kalangan masyarakat Islam telah lama menebal. Sebarang amalan yang didapati bersalahan dengan peruntukan hukum Syafi'i dianggap asing dan tidak boleh diamalkan. Meskipun demikian dalam beberapa hal yang terhad masyarakat Islam turut beramal dengan pandangan hukum mazhab-mazhab lain terutamanya dalam keadaan terdesak. Itupun diterima dalam keadaan sempit dada.

Tradisi pengamalan agama yang bertunjangkan kepada Mazhab Syafi'i, pendedahan masyarakat ilmuan dan awam kepada kepelbagaian mazhab atau perbandingan mazhab, perkembangan moden dan tuntutan semasa sedikit sebanyak menuntut kepada pertimbangan sewajarnya dalam percampuran mazhab. Oleh kerana persoalan percampuran mazhab atau talfiq mempunyai pandangan yang pro dan kontra di kalangan ulama, justeru kajian ini akan menganalisis pandangan masyarakat Islam yang diwakili golongan agamawan dan masyarakat awam di Malaysia. Pandangan mereka ini mungkin boleh mencorakkan bentuk amalan keagamaan di Malaysia nanti.

* Prof. Madya, Jabatan Fiqh \& Usul, Akademi Pengajian Islam, Universiti Malaya, Kuala Lumpur.

** Prof. Madya, Jabatan Fiqh \& Usul, Akademi Pengajian Islam, Universiti Malaya, Kuala Lumpur.

*** Prof. Madya, Jabatan Fiqh \& Usul, Akademi Pengajian Islam, Universiti Malaya, Kuala Lumpur.

**** Prof. Madya, Jabatan Fiqh \& Usul, Akademi Pengajian Islam, Universiti Malaya, Kuala Lumpur.

***** Prof. Madya, Jabatan Fiqh \& Usul, Akademi Pengajian Islam, Universiti Malaya, Kuala Lumpur.

****** Prof. Madya, Jabatan Fiqh \& Usul, Akademi Pengajian Islam, Universiti Malaya, Kuala Lumpur.

Prof. Madya, Jabatan Fiqh \& Usul, Akademi Pengajian Islam, Universiti Malaya, Kuala Lumpur. 
Terdapat beberapa kajian yang pernah dijalankan menyentuh amalan masyarakat Islam di Malaysia pada isu-isu tertentu berdasarkan percampuran nilai hukum antara pelbagai mazhab. Walau bagaimanapun sejauh penelitian yang dibuat belum terdapat kajian yang dilakukan bagi melihat penerimaan masyarakat (ilmuan agama dan masyarakat awam) terhadap amalan percampuran mazhab dalam perkara ibadat dan kekeluargaan.

\section{PERCAMPURAN MAZHAB}

Percampuran mazhab dapat difahami secara ringkasnya sebagai berpegang dengan pendapat pelbagai mazhab dan tidak terikat dengan satu-satu mazhab sahaja dalam amalan. Terdapat beberapa bentuk amalan percampuran mazhab yang ada dibincang dan disentuh dalam ilmu Ușūl Fiqh. Antaranya ialah:

\section{Talfiq}

\section{Takhayyūr}

\section{Tatabbu' al-rukhas}

\section{Tarjịh}

Istilah-istilah ini saling berkaitan antara satu sama lain sehingga terdapat ulama yang menyamakan pengertian sebahagian daripadanya dengan yang lain. Sebagai contoh Abu al-'Awn Muhammad bin Ahmad al-Safarini (1114-1188H) menyamakan pengertian talfiq dan tatabbu' al-rukhās. Manakala Yūsuf al-Qaraḍāwī pula dalam satu tulisan pernah mendatangkan definisi talfiq yang dilihat menyerupai pengertian dan konsep tarjīh.

Untuk memahami bentuk-bentuk percampuran mazhab secara lebih terperinci, berikut didatangkan definisi bagi setiap istilah tersebut :

1. TALFĪQ - Wahbah al-Zuhāyli mendefinisikannya sebagai menghimpunkan antara taqlid dua imam atau lebih dalam sesuatu perbuatan di mana setiap perbuatan itu mempunyai rukun atau juz'iyyāt yang mempunyai hubungan antara satu sama lain. Setiap perbuatan itu juga mempunyai hukum khas yang menjadi pokok perselisihan di kalangan ulama. Apabila seseorang bertaqlid kepada mazhab tertentu dalam sesuatu hukum dan bertaqlid kepada mazhab yang lain dalam masalah 
hukum yang lain, maka perbuatan itu dianggap talfiq di antara dua mazhab atau lebih ${ }^{1}$.

2. TAKHAYYUR - Proses memilih salah satu pendapat atau hukum daripada pelbagai pendapat-pendapat lain yang berbeza mazhab. ${ }^{2}$

3. TATABBU'AL-RUKHAS - Bermaksud mengambil hukum yang termudah daripada setiap mazhab pada masalah-masalah yang mendatang. ${ }^{3}$ Kemudahan yang dimaksudkan ialah pendapat para ulama yang paling mudah dan tidak membebankan. ${ }^{4}$

4. TARJIYH - Bermaksud proses memilih sesuatu pendapat berdasarkan kekuatan dalilnya. Ia merupakan salah satu bentuk ijtihad. ${ }^{5}$ Ini kerana pentarjīh perlu memiliki kemampuan untuk menganalisis pandangan-pandangan mazhab dalam sesuatu masalah dan berijtihad menentukan pandangan yang paling kuat hujahnya dan sesuai dengan keadaan semasa. Tarjīh termasuk dalam ijtihad intiq $\bar{a}{ }^{\prime} \bar{i}$ seperti yang dinyatakan oleh al-Qaradāwì. Ijtihad intiq $\bar{a} ' \bar{i}$ adalah ijtihad untuk memilih salah satu pendapat terkuat antara beberapa pendapat yang ada dalam penbendaharaan fiqh yang diwariskan oleh imam mujtahid terdahulu. ${ }^{6}$

\footnotetext{
Wahbah al-Zuhayli (1993), Al-Rukhāṣ al-Syar ‘yyah Aḥkamuhā wa Ḍawābituhā. Beirut: Dār al-Khair, h. 56.

2 Feisal Abdul Rauf (2002), Islam, a Sacred Law: What Every Muslim Should Know About The Shariah. Kuala Lumpur: Yayasan Dakwah Islam Malaysia, h. 209.

3 Wahbah al-Zuhaylì (2004), Ușūl al-Fiqh al-Istāmīi, j. 2. Beirut: Dār al- Fikr al-Mu'āșir, h. 1181.

4 Maszlee Malik (2005), Talfiq beramal dengan pelbagai Mazhab. Selangor: Karya Bestari Sdn. Bhd., h. 45.

5 Ibid., h. 43.

6 Yūsuf al-Qaraḍāwī (1987), Ijtihad Dalam Syariat Islam, H. Achmad Sy thori (terj.). Jakarta: P T Bulan Bintang, h. 150.
} 
Hubungkait Antara Percampuran Mazhab, Talfiq, Takhayyur, Tatabbū' Al-Rukhaș Dan Tarjīh

Persamaan ketara antara talfiq, takhayyur, tatabbu' al-rukhas dan tarjị ialah amalan-amalan ini menyebabkan berlakunya percampuran mazhab. Golongan yang mengamalkannya tidak berpegang tetap kepada sesuatu mazhab tertentu.

Dari aspek perbezaan pula, tarjīh merupakan salah satu cabang ijtihad. Manakala talfíq, takhayyur dan tatabbu' al-rukhās pula merupakan di antara bentuk-bentuk amalan taqlid. Oleh kerana berbeza dari aspek asas pembinaan tersebut, amalan-amalan ini mempunyai perbezaan yang ketara $^{7}$. Perbezaan antara kesemua amalan percampuran mazhab ini digambarkan dalam jadual 1 berikut :

7 Lihat: Noor Naemah Abd. Rahman. (et.al.)(2003) "Pendekatan Ijtihad tarjīhi Dalam amalan Fatwa Jemaah Ulama Negeri Kelantan : Rujukan Kepada Fatwa-fatwa 1990-an” dalam Jurnal Syariah, j. 11, bil. 2, h. 32. 
Jurnal Fiqh: No. 4 (2007) 197-222

\begin{tabular}{|c|c|c|c|c|}
\hline & 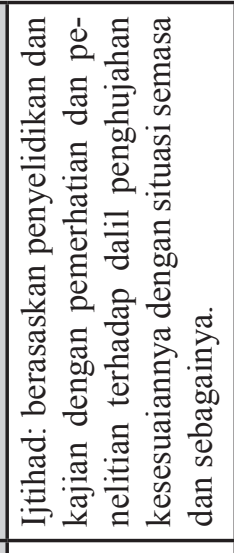 & 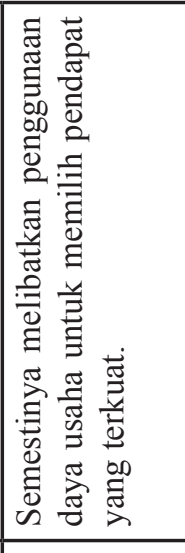 & 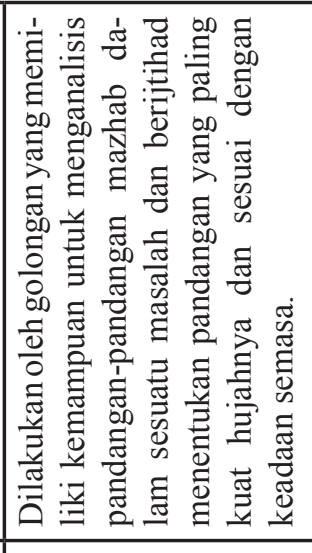 & 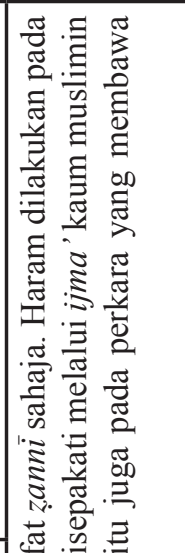 \\
\hline 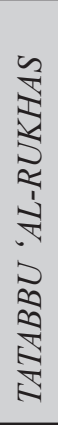 & 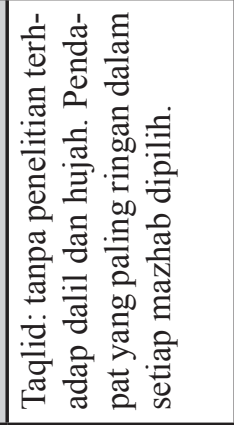 & 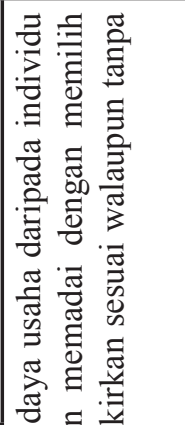 & 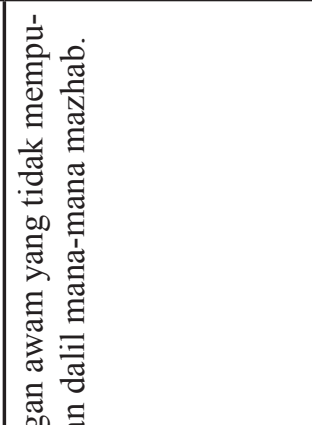 & 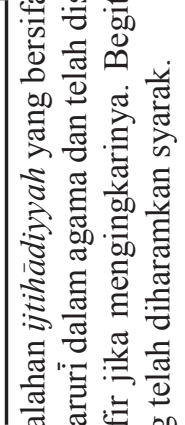 \\
\hline ¿ & 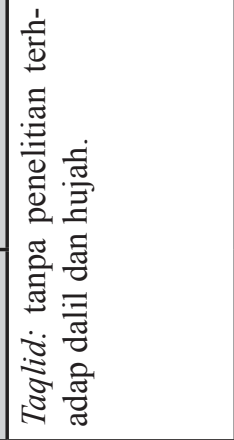 & 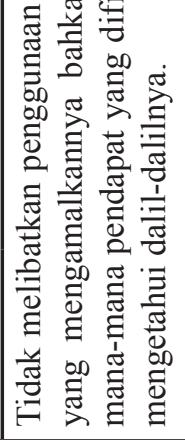 & 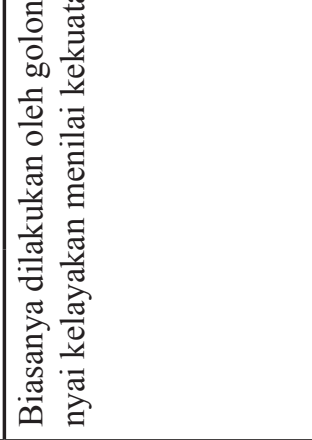 & 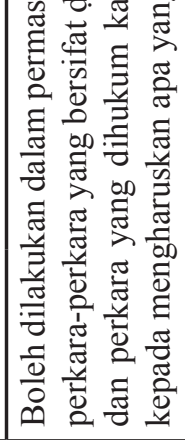 \\
\hline & 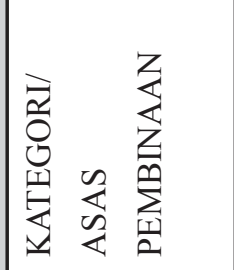 & 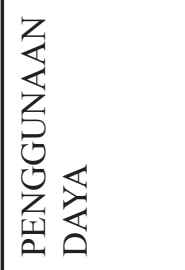 & 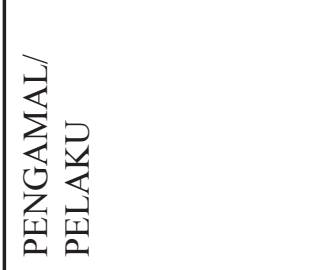 & 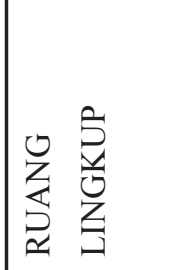 \\
\hline
\end{tabular}


Percampuran Mazhab Dalam Isu Ibadat

\begin{tabular}{|c|c|}
\hline 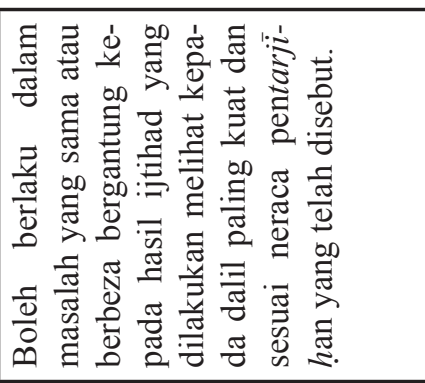 & 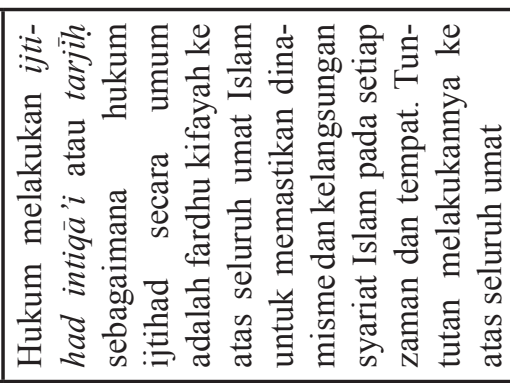 \\
\hline 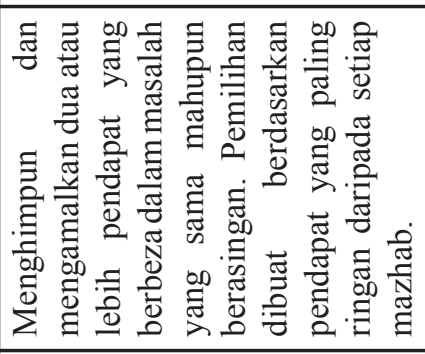 & 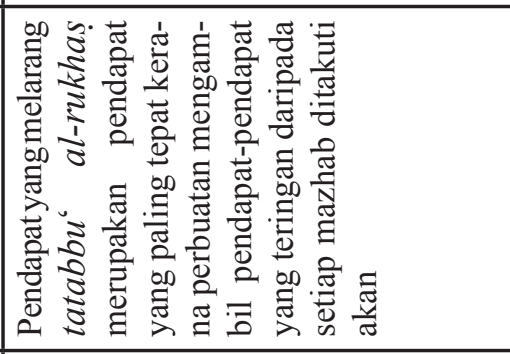 \\
\hline 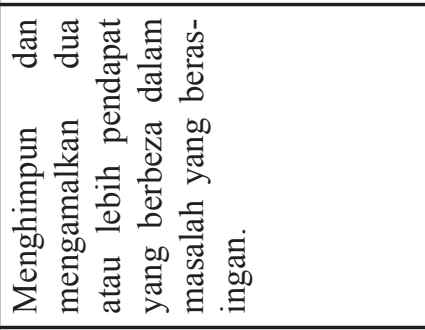 & 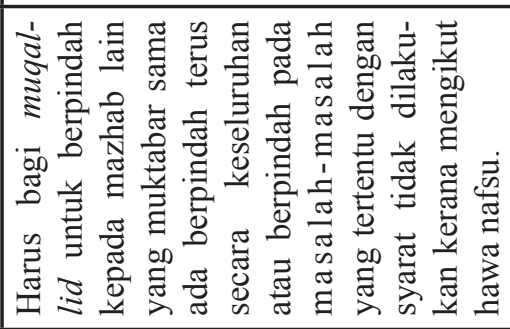 \\
\hline 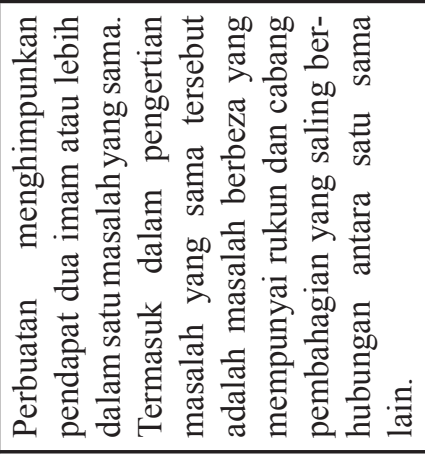 & 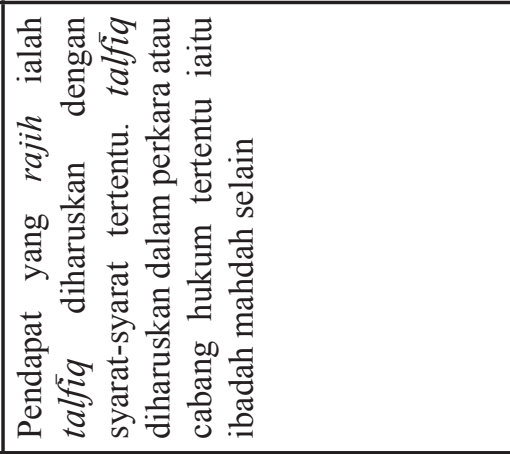 \\
\hline 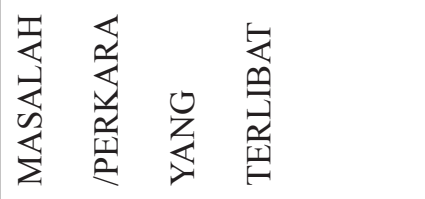 & \\
\hline
\end{tabular}


Jurnal Fiqh: No. 4 (2007) 197-222

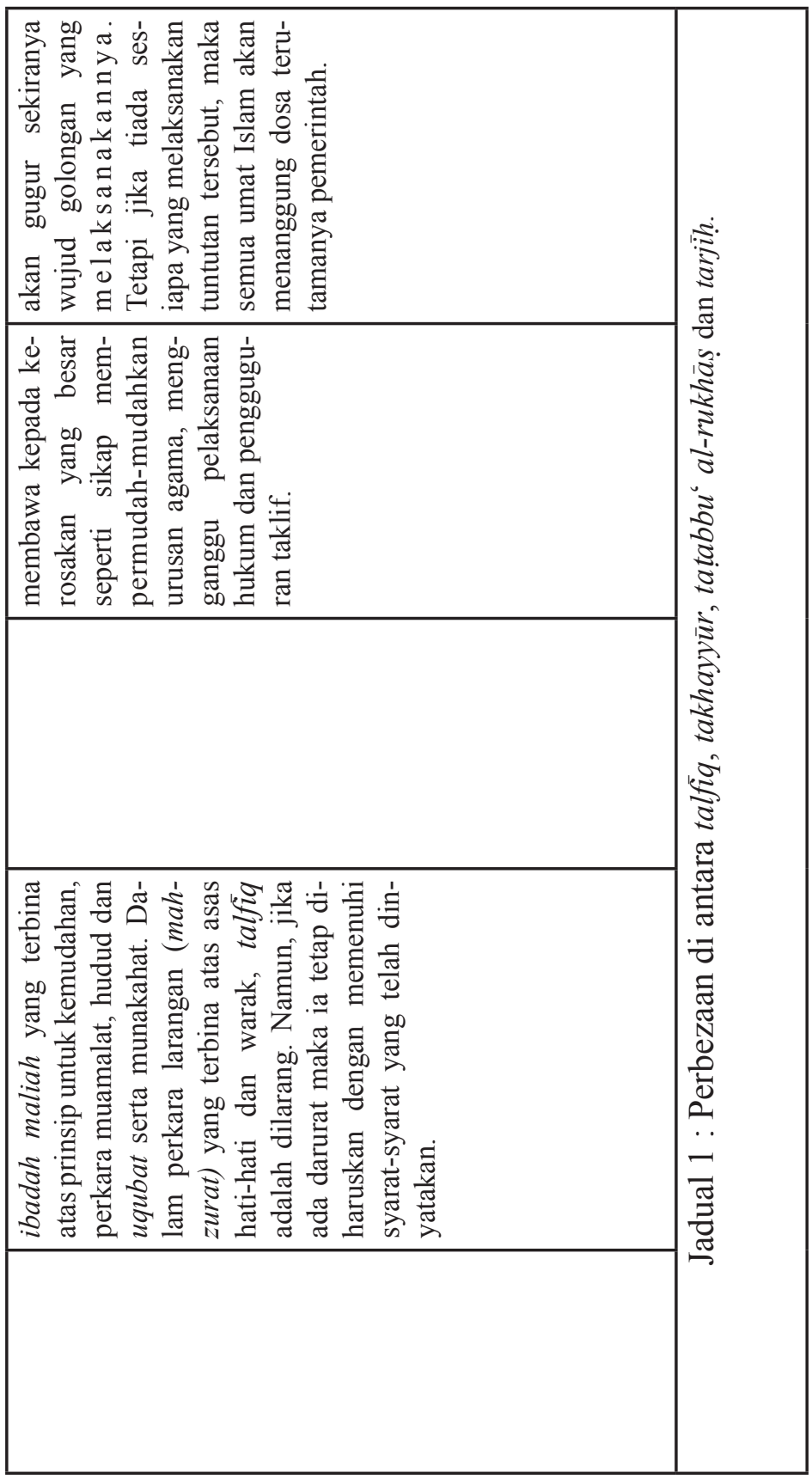




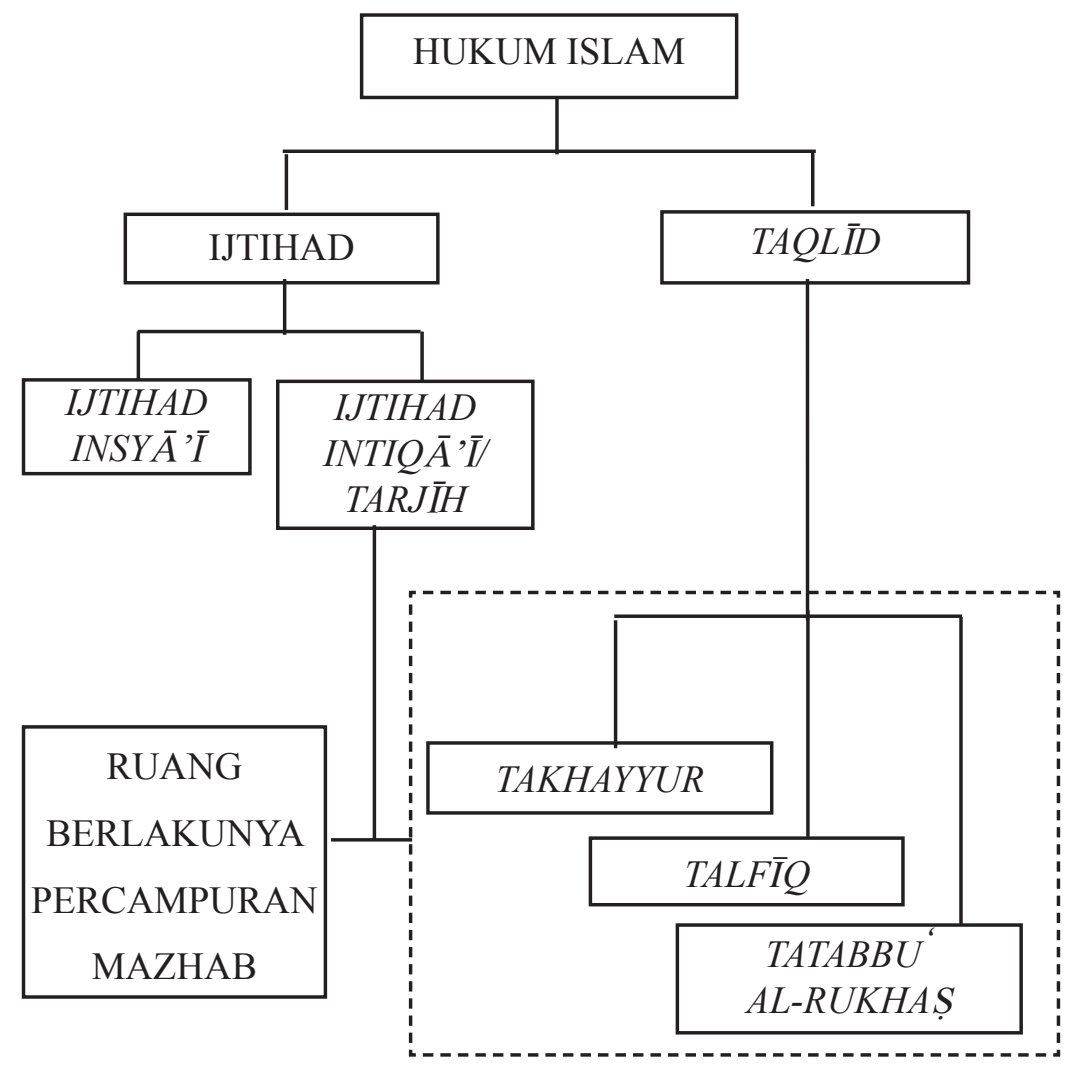

Rajah 1 : Ruang Berlakunya Percampuran Mazhab

\section{KAJIAN TERDAHULU}

Perbincangan dan ulasan secara teoritikal mengenai konsep talfiq biasanya terdapat di bahagian akhir sesebuah buku mengenai Ușūl al-Fiqh moden seperti Wahbah al-Zuhaili dalam Usūl al-Fiqh alIslämi. Perbincangan biasanya menyentuh mengenai konsep talfíq, pandangan pelbagai ulama mazhab sama ada yang menerima atau yang menolak. Karya-karya lain yang ada menyentuh isu talfiq antara lainnya ialah al-Bahr al-Muhit karangan al-Zarkasyi ; alMuwāfaqāt oleh al-Syātịibi ; I'lām al-Muwāqqi ìn karangan Ibn 
Qaiyyim, ; 'Umdah al-Tahqiq fí Hukm al-Taqlid wa al-talfíq hasil karangan Muḥammad Sa 'ìid al-Bāni dan lain-lain.

Terdapat beberapa kajian khusus mengenai talfíq di Malaysia. Namun ia tidak menfokuskan kepada penerimaan masyarakat Islam terhadap amalan percampuran mazhab atau talfiq. Antara kajian tersebut ialah :

Nizaita Omar (2004) "Pelaksanaan Ibadat Solat Bagi Pesakit: Kajian Hukum Berasaskan Realiti Semasa". Tesis ini membincangkan permasalahan wuduk, tayammum dan caracara solat bagi pesakit yang menghidap pelbagai penyakit yang menyukarkan untuk berwuduk dan bersolat. Kajian ini mengemukakan pandangan fuqaha mazhab dan hujah, kemudian mentarjīhkan masalah tersebut mengikut pandangan mazhab yang dikira kuat hujahnya dan tidak mernyusahkan pesakit. Penulisan ini tidak menyentuh masalah talfiq mazhab secara langsung.

Saifuddin Salleh (2003) dalam disertasi beliau yang bertajuk "Talfíq Dalam Perkara Ibadat di Kalangan Masyarakat Islam di Malaysia: Satu Penilaian Hukum" membincangkan teori talfiq dan hubungannya dengan taqlid dan tatabbu al-rukhas. Penulisan ini juga menyentuh hukum talfiq kepada masyarakat awam. Tumpuan kajian kepada amalan talfiq dalam masyarakat Malaysia dan hubungannya dengan tradisi keterikatan mazhab. Contoh-contoh yang dikemukakan seperti bersuci bagi pesakit yang disimen anggota wuduk, bersentuhan tanpa membatalkan wuduk, tidak menyebut lafaz uṣalli, meninggalkan doa qunut dan lain-lain.

Bagaimanapun, kajian ini tidak membuat penilaian terhadap penerimaan masyarakat. Secara khususnya, tumpuan diberikan kepada penilaian hukum berkenaan amalan-amalan yang disebut di atas. Kajian ini menyimpulkan bahawa talfiq yang berlaku

8 Nizaita Omar (2004) "Pelaksanaan Ibadat Solat Bagi Pesakit: Kajian Hukum Berasaskan Realiti Semasa", Tesis Ph.D, Jabatan Fiqh \& Usul, Akademi Pengajian Islam, Universiti Malaya, Kuala Lumpur.

9 Saifuddin Salleh (2003), "Talfiq Dalam Perkara Ibadat di Kalangan Masyarakat Islam di Malaysia: Satu Penilaian Hukum”, Disertasi Sarjana, Jabatan Fiqh \& Usul, Akademi Pengajian Islam, Universiti Malaya, Kuala Lumpur. 
dalam amalan-amalan yang dikaji adalah harus kerana ia bertujuan memberi kemudahan kepada masyarakat Islam untuk menunaikan ibadat.

Amir Hamzah Mohd Ali (2003) dalam penulisannya mengenai "Talfiq Dalam Pelaksanaan Ibadah Solat Fardhu: Kajian Di Kalangan Mahasiswa APIUM"10 tertumpu kepada ibadat solat dan responden adalah pelajar-pelajar Akademi Pengajian Islam, Universiti Malaya sahaja. Pengumpulan data menggunakan kaedah soal selidik. Dapatan kajian, menunjukan bahawa kebanyakan pelajar beramal dengan talfiq yang dibenarkan oleh Syarak dalam pelaksanaan solat.

Secara ringkasnya, kajian-kajian di atas tidak membincangkan penerimaan masyarakat Islam terhadap amalan percampuran mazhab (talfiq). Ia lebih tertumpu kepada apa yang diamalkan berasaskan percampuran mazhab. Justeru, terdapat ruang besar bagi kajian ini dijalankan untuk mendapat data dan input bagi merancang corak pengamalan keagamaan di Malaysia.

\section{METODOLOGI KAJIAN}

Kajian ini melibatkan dua kaedah utama iaitu kaedah penyelidikan teoritikal dan empirikal. Melalui kaedah teoritikal, kajian perpustakaan dilakukan untuk mengumpul maklumat awal mengenai latar belakang kajian iaitu aspek-aspek percampuran mazhab dalam bidang ibadat dan kekeluargaan akan diaplikasikan. Melalui kaedah ini sumber-sumber primari dan dan sekunder akan dikaji. Ianya akan melibatkan kajian terhadap buku-buku, artikel ilmiah, jurnal, latihan-latihan ilmiah, kompilasi fatwa, akhbar dan majalah serta buletin. Kajian ini juga akan melibatkan kaedah dokumentasi dan historis.

Kaedah penyelidikan empirikal pula melibatkan dua peringkat iaitu pengumpulan dan analisis data. Kajian ini juga akan mengumpulkan data-data primari dan sekondari. Untuk data primari, maklumat akan diperolehi melalui kajian lapangan.

\footnotetext{
10 Amir Hamzah Mohd Ali (2003), "Talfiq Dalam Pelaksanaan Ibadah Solat Fardhu: Kajian Di Kalangan Mahasiswa APIUM”, Latihan Ilmiah, Jabatan Fiqh \& Usul, Akademi Pengajian Islam, Universiti Malaya, Kuala Lumpur.
} 
Penyelidik menggunakan beberapa metode dalam kajian ini, iaitu persampelan, temubual yang berstruktur dan soal selidik.

Melalui metode persampelan, penyelidik menggunakan kaedah strata untuk menentukan negeri yang akan dikaji. Enam buah negeri telah dipilih berdasarkan darjah keterikatannya dengan sesuatu mazhab fiqh. Negeri-negeri tersebut ialah Kelantan, Kedah, Johor, Perlis, Pahang, Wilayah Persekutuan dan Selangor. Metode temubual berstruktur pula akan menyusul untuk mendapatkan maklumat yang diperlukan. Responden yang terlibat ialah pegawai atasan di institusi penguatkuasa agama negeri-negeri, guru-guru pondok dan tokoh-tokoh agama. Kaedah ini digunakan untuk mendapatkan maklumat tentang kecenderungan pihak berkuasa agama, tokoh-tokoh agama dan guru-guru pondok terhadap isu percampuran mazhab dalam aspek ibadat. Metode soal selidik digunakan untuk menilai penerimaan masyarakat terhadap amalan percampuran mazhab dalam aspek ibadat. Responden yang terdiri daripada masyarakat setempat akan dipilih.

Peringkat kedua dalam metode empirikal ini ialah pemprosesan dan analisis data. Data-data yang diperolehi melalui kaedah temubual dianalisis secara deduktif, induktif dan komparatif. Manakala data-data yang diperolehi melalui kaedah soal selidik dianalisis menggunakan kaedah SPSS edisi ke-11. Antara kaedah statistik yang digunakan adalah kaedah analisis diskriktif yang melibatkan jadual silang. Seterusnya inferens yang diperolehi digunakan untuk perbincangan, membuat rumusan dan mengemukakan cadangan kajian.

\section{KEPUTUSAN DAN INTERPRETASI DATA KAJAN}

Kajian tentang penerimaan masyarakat Islam di Malaysia terhadap amalan percampuran mazhab dalam isu-isu ibadat ini telah dijalankan dalam bentuk soal selidik ke atas 414 orang responden yang dipilih.

\section{Ciri Demografi}

Dalam kajian ini jenis persampelan purposif telah dipilih. Responden yang dipilih adalah golongan yang mempunyai latar belakang pendidikan agama dan memahami sedikit sebanyak 
berkenaan mazhab dalam Islam. Taburan demografi responden adalah seperti di dalam jadual 2 :

Jadual 2 : Taburan kekerapan dan peratusan responden mengikut pembolehubah demografi.

\begin{tabular}{|c|c|c|}
\hline \multicolumn{2}{|c|}{ Pembolehubah } & Kekerapan \\
\hline \multirow{2}{*}{ Jantina } & Lelaki & $239(58.6 \%)$ \\
\hline & Perempuan & $169(41.4 \%)$ \\
\hline \multirow{6}{*}{ Umur } & $20-29$ tahun & $135(32.8 \%)$ \\
\hline & $30-39$ tahun & $166(40.3 \%)$ \\
\hline & $40-49$ tahun & $67(16.3 \%)$ \\
\hline & $50-59$ tahun & $34(8.3 \%)$ \\
\hline & $60-60$ tahun & $9(2.2 \%)$ \\
\hline & 70 tahun ke atas & $1(0.2 \%)$ \\
\hline \multirow{2}{*}{$\begin{array}{l}\text { Aliran } \\
\text { pendidikan }\end{array}$} & Agama & $341(84.4 \%)$ \\
\hline & Akademik & $61(15.2 \%)$ \\
\hline \multirow{8}{*}{$\begin{array}{l}\text { Pendidikan } \\
\text { tertinggi }\end{array}$} & SPM & $41(10.1 \%)$ \\
\hline & STPM & $26(6.4 \%)$ \\
\hline & STO & $13(3.2 \%)$ \\
\hline & Sijil & $14(3.4 \%)$ \\
\hline & Diploma & $49(12.1 \%)$ \\
\hline & Sarjana Muda & $172(42.4 \%)$ \\
\hline & Sarjana & $77(19.0 \%)$ \\
\hline & Ph.D & $14(3.4 \%)$ \\
\hline \multirow{5}{*}{$\begin{array}{l}\text { Institusi } \\
\text { pendidikan } \\
\text { (Dalam } \\
\text { negara) }\end{array}$} & IPTA & $269(65.9 \%)$ \\
\hline & IPTS & $24(7.6 \%)$ \\
\hline & Pengajian pondok & $41(12.9 \%)$ \\
\hline & Pengajian tidak formal & $37(11.7 \%)$ \\
\hline & Lain-lain & $6(1.9 \%)$ \\
\hline \multirow{7}{*}{$\begin{array}{l}\text { Institusi } \\
\text { pendidikan } \\
\text { (Luar } \\
\text { negara) }\end{array}$} & Mesir & $74(57.8 \%)$ \\
\hline & Arab Saudi & $7(5.5 \%)$ \\
\hline & Jordan & $12(9.4 \%)$ \\
\hline & Sudan & $1(0.8 \%)$ \\
\hline & Indonesia & $11(8.6 \%)$ \\
\hline & OK & $4(3.1 \%)$ \\
\hline & Lain-lain & $19(14.8 \%)$ \\
\hline \multirow{10}{*}{ Pekerjaan } & Mufti & $5(1.4 \%)$ \\
\hline & Hakim Mahkamah Syariah & $6(1.6 \%)$ \\
\hline & Pensyarah & $80(22.0 \%)$ \\
\hline & Peguam Syarie & $1(0.3 \%)$ \\
\hline & Pegawai Tadbir & $61(16.8 \%)$ \\
\hline & Guru & $110(30.2 \%)$ \\
\hline & Imam/bilal masjid & $23(6.3 \%)$ \\
\hline & Penceramah agama & $14(3.8 \%)$ \\
\hline & Pegawai Jabatan Agama Islam & $44(12.1 \%)$ \\
\hline & Lain-lain & $20(5.5 \%)$ \\
\hline
\end{tabular}




\begin{tabular}{|c|c|c|}
\hline \multirow{14}{*}{ Negeri asal } & Perlis & $22(5.4 \%)$ \\
\hline & Kedah & $89(21.8 \%)$ \\
\hline & Pulau Pinang & $10(2.4 \%)$ \\
\hline & Perak & $25(6.1 \%)$ \\
\hline & Selangor & $15(3.7 \%)$ \\
\hline & Melaka & $6(1.5 \%)$ \\
\hline & Negeri Sembilan & $13(3.2 \%)$ \\
\hline & Johor & $47(11.5 \%)$ \\
\hline & Pahang & $6(1.5 \%)$ \\
\hline & Terengganu & $74(18.1 \%)$ \\
\hline & Kelantan & $93(22.7 \%)$ \\
\hline & Sarawak & $2(0.5 \%)$ \\
\hline & Sabah & $1(0.2)$ \\
\hline & WP Kuala Lumpur & $6(1.5 \%)$ \\
\hline \multirow{5}{*}{$\begin{array}{l}\text { Mazhab } \\
\text { yang } \\
\text { dipegang }\end{array}$} & Hanafi & $2(0.5 \%)$ \\
\hline & Maliki & $1(0.2 \%)$ \\
\hline & Syafi'i & $390(95.6 \%)$ \\
\hline & Hanbali & - \\
\hline & Tidak bermazhab & $15(3.7 \%)$ \\
\hline
\end{tabular}

Data yang diperolehi dalam kajian ini diwakili oleh responden lelaki sebanyak $58.6 \%$ melebihi responden wanita yang mewakili $41.4 \%$. Majoriti responden adalah daripada golongan yang muda iaitu dari julat umur 30 - 39 tahun sebanyak $40.3 \%, 20-29$ tahun sebanyak $32.8 \%$ diikuti dengan golongan berusia 40 - 49 tahun sebanyak $16.3 \%$. Walaupun kajian lebih mensasarkan golongan yang berpendidikan agama sebagai sampel, namun wujud responden yang datang dari latar belakang pendidikan akademik sebanyak $15.2 \%$. Lebih separuh daripada responden mempunyai tahap pendidikan yang tinggi iaitu $42.4 \%$ berkelulusan sarjana muda, 19\% berkelulusan sarjana dan 3.4\% berkelulusan Ph.D. Kebanyakan responden menerima pendidikan mereka dari institusi pendidikan di dalam Malaysia iaitu seramai 377 orang termasuk mereka yang menerima pengajian tidak formal sebanyak $11.7 \%$.

Daripada keseluruhan responden hanya 128 orang sahaja yang menerima pendidikan dari luar negara dan majoritinya berkelulusan dari Mesir sebanyak 57.8\%. Responden berasal dari berbagai-bagai profesyen kerjaya. Guru merupakan kerjaya tertinggi iaitu sebanyak $30.2 \%$ diikuti pensyarah sebanyak $22 \%$, pegawai tadbir sebanyak $16.8 \%$ dan pegawai Jabatan Agama Islam sebanyak $12.1 \%$. responden mewakili semua negeri di Malaysia namun bilangan responden tidak seimbang antara satu sama lain berikutan pengedaran borang soal selidik yang tidak dibuat ke 
semua negeri. Jumlah responden paling ramai berasal dari Kelantan sebanyak $22.7 \%$ diikuti oleh Kedah iaitu sebanyak $21.8 \%$, Terengganu $18.1 \%$ dan Johor sebanyak $11.5 \%$. Walaupun responden berasal dari pelbagai latar belakang, namun majoritinya adalah bermazhab Syafi' $i$ iaitu 95.6\%. Hanya segelintir sahaja daripada responden sahaja yang mengaku tidak bermazhab iaitu sebanyak 15 orang $(3.7 \%)$, bermazhab Hanafi sebanyak 2 orang $(0.5 \%)$ dan bermazhab Maliki sebanyak seorang yang mewakili $0.2 \%$.

\section{Hubungan Latar Belakang Dengan Mazhab Yang Dipegangi}

Tujuan utama kajian ini dijalankan bukan untuk menguji atau mengkaji faktor yang menyebabkan pemilihan dan pegangan mazhab oleh masyarakat Malaysia. Data yang diperolehi juga adalah tidak mencukupi untuk menguji perkara tersebut. Ini kerana jumlah pengikut mazhab selain Syafi'i adalah terlalu kecil berbanding pengikut mazhab Syafi'i yang mewakili hanya $4.4 \%$ sahaja. Namun penyelidik tertarik untuk memperincikan latar belakang pengikut mazhab selain Syafi'i di Malaysia untuk mengetahui secara umum faktor yang mungkin mempengaruhi pemilihan mazhab tersebut. Taburan responden dan pemilihan mazhab diperincikan seperti dalam jadual 3, jadual 4, jadual 5 dan jadual 6.

Jadual 3 : Kekerapan umur responden dan hubungannya dengan mazhab yang dipegangi.

\begin{tabular}{|l|c|c|c|c|c|}
\hline \multirow{2}{*}{ Umur } & \multicolumn{4}{|c|}{ Mazhab yang dipegangi } & \multirow{2}{*}{ Jumlah } \\
\cline { 2 - 5 } & Hanafi & Maliki & Syafi ${ }^{\circ} i$ & $\begin{array}{c}\text { Tidak } \\
\text { bermazhab }\end{array}$ & \\
\hline $\begin{array}{l}20-29 \\
\text { tahun }\end{array}$ & 0 & $1(0.8 \%)$ & $131(98.5 \%)$ & $1(0.8 \%)$ & 133 \\
\hline $\begin{array}{l}30-39 \\
\text { tahun }\end{array}$ & $1(0.6 \%)$ & 0 & $159(97.5 \%)$ & $3(1.8 \%)$ & 163 \\
\hline $\begin{array}{l}40-49 \\
\text { tahun }\end{array}$ & 0 & 0 & $64(97 \%)$ & $2(3 \%)$ & 66 \\
\hline $\begin{array}{l}50-59 \\
\text { tahun }\end{array}$ & $1(2.9 \%)$ & 0 & $27(79.4 \%)$ & $6(17.6 \%)$ & 34 \\
\hline $\begin{array}{l}60-69 \\
\text { tahun }\end{array}$ & 0 & 0 & $6(66.7 \%)$ & $3(33.3 \%)$ & 9 \\
\hline $\begin{array}{l}70 \text { tahun } \\
\text { ke atas }\end{array}$ & 0 & 0 & 1 & 0 & 1 \\
\hline Jumlah & 2 & 1 & 388 & 15 & 406 \\
\hline
\end{tabular}


Jurnal Fiqh: No. 4 (2007) 197-222

Jadual 4: Kekerapan aliran pendidikan responden dan hubungannya dengan mazhab yang menjadi pegangan.

\begin{tabular}{|l|c|c|c|c|c|}
\hline \multirow{2}{*}{$\begin{array}{c}\text { Aliran } \\
\text { pendidikan }\end{array}$} & \multicolumn{4}{|c|}{ Mazhab yang dipegangi } & \multirow{2}{*}{ Jumlah } \\
\cline { 2 - 5 } & $\begin{array}{c}\text { Mazhab } \\
\text { Hanafi }\end{array}$ & $\begin{array}{c}\text { Mazhab } \\
\text { Maliki }\end{array}$ & $\begin{array}{c}\text { Mazhab } \\
\text { Syafi' }{ }^{\circ} i\end{array}$ & $\begin{array}{c}\text { Tidak } \\
\text { Bermazhab }\end{array}$ & \\
\hline Agama & 2 & 1 & 329 & 6 & 338 \\
\hline Akademik & 0 & 0 & 52 & 8 & 60 \\
\hline
\end{tabular}

Jadual 5 : Kekerapan tahap pendidikan responden dan hubungannya dengan mazhab yang dipegangi.

\begin{tabular}{|l|c|c|c|c|c|}
\hline \multirow{2}{*}{$\begin{array}{l}\text { Tahap } \\
\text { pendidikan }\end{array}$} & \multicolumn{4}{|c|}{ Mazhab yang dipegangi } & \multirow{2}{*}{ Jumlah } \\
\cline { 2 - 5 } & Hanafi & Maliki & Syafi ${ }^{\circ} \mathrm{i}$ & $\begin{array}{l}\text { Tidak } \\
\text { bermazhab }\end{array}$ & \\
\hline SPM & 0 & 0 & 34 & 5 & 39 \\
\hline STPM & 0 & 0 & 25 & 1 & 26 \\
\hline STU & 0 & 0 & 13 & 0 & 13 \\
\hline Sijil & 0 & 0 & 14 & 0 & 14 \\
\hline Diploma & 0 & 0 & 45 & 3 & 48 \\
\hline Sarjana Muda & 1 & 1 & 163 & 4 & 169 \\
\hline Sarjana & 1 & 0 & 75 & 1 & 77 \\
\hline PhD & 0 & 0 & 13 & 1 & 14 \\
\hline Jumlah & 2 & 1 & 382 & 15 & 400 \\
\hline
\end{tabular}

Jadual 6 : Kekerapan negeri asal responden dan hubungannya dengan mazhab yang dipegangi.

\begin{tabular}{|c|c|c|c|c|c|}
\hline \multirow[b]{2}{*}{ Negeri asal } & \multicolumn{4}{|c|}{ Mazhab yang dipegangi } & \multirow[b]{2}{*}{ Jumlah } \\
\hline & Hanafi & Maliki & Syafi‘ $i$ & $\begin{array}{l}\text { Tidak } \\
\text { bermazhab }\end{array}$ & \\
\hline Perlis & 0 & 0 & 13 & 9 & 22 \\
\hline Kedah & 0 & 1 & 85 & 2 & 88 \\
\hline Pulau Pinang & 0 & 0 & 9 & 1 & 10 \\
\hline Perak & 0 & 0 & 25 & 0 & 25 \\
\hline Selangor & 0 & 0 & 15 & 0 & 15 \\
\hline Melaka & 0 & 0 & 6 & 0 & 6 \\
\hline Negeri Sembilan & 0 & 0 & 13 & 0 & 13 \\
\hline Johor & 0 & 0 & 45 & 1 & 46 \\
\hline Pahang & 0 & 0 & 6 & 0 & 6 \\
\hline Terengganu & & 0 & 69 & 1 & 71 \\
\hline Kelantan & 1 & 0 & 91 & 1 & 93 \\
\hline Sarawak & 0 & 0 & 2 & 0 & 2 \\
\hline Sabah & 0 & 0 & 1 & 0 & \\
\hline WP Kuala Lumpur & 0 & 0 & 6 & 0 & 6 \\
\hline Jumlah & 2 & 1 & 386 & 15 & 404 \\
\hline
\end{tabular}


Daripada data yang diperolehi, didapati bahawa mazhab Syafi ‘ $i$ masih lagi menjadi pegangan majoriti masyarakat Malaysia dan hanya sebilangan kecil sahaja yang mengaku mengikut mazhab yang lain atau tidak bermazhab. Sebanyak 95.6\% responden daripada pelbagai peringkat umur, aliran pendidikan, tahap pendidikan dan negeri adalah bermazhab Syafi' $i$.

Pengikut mazhab Hanafi seramai 2 orang dan mazhab Maliki seramai seorang dalam kajian ini berasal dari golongan yang beraliran agama dan mempunyai tahap pendidikan yang tinggi iaitu dalam kalangan sarjana muda dan sarjana. Namun mereka tidak datang dari satu peringkat umur sahaja. Pengikut mazhab Hanafi datang dari lingkungan umur 30 - 39 tahun dan 50 - 59 tahun manakala pengikut mazhab Maliki pula berumur $20-29$ tahun.

Golongan yang mengaku tidak berpegang dengan manamana mazhab sebanyak $3.7 \%$ iaitu 15 orang datang dari semua peringkat umur kecuali 70 tahun ke atas. Golongan yang berlatar belakang pendidikan akademik yang tidak bermazhab adalah sebanyak 8 orang mewakili $13.3 \%$ daripada 52 orang jumlah keseluruhan manakala golongan berpendidikan agama sebanyak $1.8 \%$ iaitu 6 daripada 338. Data ini menunjukkan bahawa mereka yang tidak bermazhab datang lebih ramai datang dari golongan akademik berbanding golongan agama. Penilaian ini dilihat dari sudut peratusan.

Analisis dari aspek negeri asal menunjukkan negeri Perlis, Kedah, Pulau Pinang, Terengganu dan Kelantan mempunyai responden yang berpegang kepada mazhab yang pelbagai. Kelima-lima negeri ini mempunyai responden yang bermazhab Syafi' $i$ dan tidak bermazhab. Responden yang bermazhab Maliki berasal dari negeri Kedah manakala mazhab Hanafi berasal pula dari Kelantan dan Terengganu. Responden dari negeri-negeri lain semuanya bermazhab Syafi ' $i$. Negeri Perlis mempunyai peratusan responden yang tidak bermazhab yang paling ramai iaitu $40.9 \%$ berbanding negeri-negeri lain. 


\section{Penerimaan Masyarakat Malaysia Terhadap Percampuran Mazhab}

Penerimaan masyarakat Malaysia terhadap isu percampuran mazhab diukur dengan melihat jumlah peratusan jawapan yang bersandar kepada mazhab selain Syafi'i yang menjadi pilihan responden mazhab Syafi'i. Percampuran mazhab berlaku sekiranya pengikut mazhab Syafi'i memilih jawapan yang bersandarkan mazhab selain Syafi'i. Daripada analisis yang dilakukan, penyelidik mendapati percampuran mazhab berlaku dalam semua soalan yang dikemukakan meliputi isu taharah, wudhu', solat, puasa dan zakat. Namun begitu, tahap percampuran mazhab dalam isu-isu tersebut berbeza antara satu soalan dengan soalan yang lain. Ini mungkin dipengaruhi oleh faktor-faktor tertentu. Dalam bahagian ini, penulis akan menyenaraikan 26 soalan tersebut mengikut pengkelasan tahap percampuran mazhab yang berlaku. Pengkelasan tersebut dibahagikan berdasarkan jumlah peratusan yang diperolehi oleh jawapan yang bersandarkan mazhab selain Syafi'i. Pengkelasan tahap percampuran yang telah ditetapkan adalah seperti dalam jadual 7 :

Jadual 7 : Tahap amalan dan penerimaan percampuran mazhab

\begin{tabular}{|c|c|}
\hline Peratusan & $\begin{array}{c}\text { Tahap Amalan dan } \\
\text { Penerimaan }\end{array}$ \\
\hline $0-49 \%$ & Rendah \\
\hline $50-79 \%$ & Sederhana \\
\hline $80-100 \%$ & Tinggi \\
\hline
\end{tabular}

Senarai soalan dan tahap percampuran mazhab yang berlaku di dalam persoalan tersebut adalah seperti dalam jadual 8 , jadual 9 dan 10. 
Jadual 8 : Isu-isu ibadat yang berlaku percampuran mazhab yang tinggi di kalangan responden bermazhab Syafi' $i$.

\begin{tabular}{|c|l|c|c|c|c|}
\hline $\begin{array}{l}\text { No. } \\
\text { Item }\end{array}$ & Soalan & $\begin{array}{c}\text { Jawapan } \\
\text { Mazhab } \\
\text { Syafi'i }\end{array}$ & $\begin{array}{c}\text { Jawapan } \\
\text { Mazhab } \\
\text { Selain } \\
\text { Syafíi }\end{array}$ & $\begin{array}{c}\text { Tidak } \\
\text { Pasti }\end{array}$ & Jumlah \\
\hline B28 & $\begin{array}{l}\text { Dengan apakah } \\
\text { pembayaran zakat } \\
\text { fitrah ditunaikan? }\end{array}$ & $\begin{array}{c}43 \\
(11.3 \%)\end{array}$ & $\begin{array}{l}\mathbf{3 3 8} \\
\mathbf{( 8 8 . 7 \% )}\end{array}$ & 0 & $\begin{array}{c}381 \\
(100 \%)\end{array}$ \\
\hline $\begin{array}{l}\text { berniat puasa } \\
\text { tetapi telah terlupa } \\
\text { hari tertentu pada } \\
\text { bulan Ramadhan } \\
\text { tersebut. }\end{array}$ & $\begin{array}{c}56 \\
(14.9 \%)\end{array}$ & $\begin{array}{c}\mathbf{3 2 0} \\
\mathbf{( 8 5 . 1 \% )}\end{array}$ & 0 & $\begin{array}{c}376 \\
(100 \%)\end{array}$ \\
\hline B41 & $\begin{array}{l}\text { Cara pembayaran } \\
\text { zakat padi. }\end{array}$ & $\begin{array}{c}61 \\
(17.3 \%)\end{array}$ & $\mathbf{2 9 2}$ & 0 & 353 \\
\hline
\end{tabular}

Jadual 9 : Isu-isu ibadat yang berlaku percampuran mazhab secara sederhana di kalangan responden bermazhab Syafi‘ $i$.

\begin{tabular}{|c|c|c|c|c|c|}
\hline $\begin{array}{l}\text { No. } \\
\text { Item }\end{array}$ & Soalan & 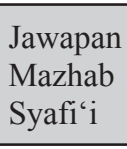 & $\begin{array}{l}\text { Jawapan } \\
\text { Mazhab } \\
\text { Selain } \\
\text { Syafi'i }\end{array}$ & $\begin{array}{l}\text { Tidak } \\
\text { Pasti }\end{array}$ & Jumlah \\
\hline B44 & $\begin{array}{l}\text { Adakah anda } \\
\text { menolak keperluan } \\
\text { asasi (nafkah diri dan } \\
\text { keluarga) sebelum } \\
\text { membayar zakat? }\end{array}$ & $\begin{array}{c}80 \\
(22.9 \%)\end{array}$ & $\begin{array}{c}270 \\
(77.1 \%)\end{array}$ & 0 & $\begin{array}{c}350 \\
(100 \%)\end{array}$ \\
\hline B40 & $\begin{array}{l}\text { Cara pembayaran } \\
\text { zakat pendapatan. }\end{array}$ & $\begin{array}{c}61 \\
(31.8 \%)\end{array}$ & $\begin{array}{c}131 \\
(68.2 \%)\end{array}$ & 0 & 192 \\
\hline B43 & $\begin{array}{l}\text { Cara pembayaran } \\
\text { zakat KWSP }\end{array}$ & $\begin{array}{c}54 \\
(34.0 \%)\end{array}$ & $\begin{array}{c}105 \\
(66.0 \%)\end{array}$ & 0 & 159 \\
\hline B14 & $\begin{array}{l}\text { Adakah pesakit } \\
\text { perlu mengqadha' } \\
\text { semula solatnya } \\
\text { yang ditinggalkan } \\
\text { ketika sakit selepas } \\
\text { sembuh? }\end{array}$ & $\begin{array}{c}112 \\
(32.8 \%)\end{array}$ & $\begin{array}{c}219 \\
(64.2 \%)\end{array}$ & $\begin{array}{c}16 \\
(4.7 \%)\end{array}$ & 341 \\
\hline
\end{tabular}


Jurnal Fiqh: No. 4 (2007) 197-222

\begin{tabular}{|c|c|c|c|c|c|}
\hline B13 & $\begin{array}{c}\text { Adakah perlu } \\
\text { berwudhu' dahulu } \\
\text { sebelum memakai } \\
\text { simen/belat/ plaster? }\end{array}$ & $\begin{array}{c}106 \\
(36.1 \%)\end{array}$ & $\begin{array}{c}\mathbf{1 7 2} \\
\mathbf{( 5 8 . 7 \% )}\end{array}$ & $\begin{array}{c}15 \\
(5.1 \%)\end{array}$ & 293 \\
\hline B12 & $\begin{array}{c}\text { Berwudhu' bagi } \\
\text { pesakit yang disimen } \\
\text { kakinya }\end{array}$ & $\begin{array}{c}156 \\
(41.4 \%)\end{array}$ & $\begin{array}{c}\mathbf{2 2 0} \\
\mathbf{( 5 8 . 5 \% )}\end{array}$ & 0 & 376 \\
\hline B31 & $\begin{array}{c}\text { Memasukkan glukos } \\
\text { ke dalam badan } \\
\text { ketika berpuasa } \\
\text { melalui saluran urat } \\
\text { (infusi). }\end{array}$ & $\begin{array}{c}147 \\
(38.9 \%)\end{array}$ & $\begin{array}{c}\mathbf{2 0 4} \\
\mathbf{( 5 4 . 0 \% )}\end{array}$ & $\begin{array}{c}27 \\
(7.1 \%)\end{array}$ & 378 \\
\hline
\end{tabular}

Jadual 10 : Isu-isu ibadat yang berlaku percampuran mazhab yang rendah di kalangan responden bermazhab Syafi' $i$.

\begin{tabular}{|c|c|c|c|c|c|}
\hline $\begin{array}{l}\text { No. } \\
\text { Item }\end{array}$ & Soalan & $\begin{array}{c}\text { Jawapan } \\
\text { Mazhab } \\
\text { Syafi'i }\end{array}$ & $\begin{array}{l}\text { Jawapan } \\
\text { Mazhab } \\
\text { Selain } \\
\text { Syafi'i }\end{array}$ & $\begin{array}{l}\text { Tidak } \\
\text { Pasti }\end{array}$ & Jumlah \\
\hline B30 & $\begin{array}{l}\text { Memasukkan saluran } \\
\text { getah ke dalam zakar } \\
\text { untuk menyalurkan } \\
\text { kencing (ihlil) ketika } \\
\text { berpuasa. }\end{array}$ & $\begin{array}{c}156 \\
(41.3 \%)\end{array}$ & $\begin{array}{c}187 \\
(49.6 \%)\end{array}$ & $\begin{array}{c}34 \\
(9.0 \%)\end{array}$ & 377 \\
\hline B22 & $\begin{array}{l}\text { Solat Jumaat di } \\
\text { masjid yang tiada } \\
\text { pemastautin }\end{array}$ & $\begin{array}{c}220 \\
(57.4 \%)\end{array}$ & $\begin{array}{c}131 \\
(34.2 \%)\end{array}$ & $\begin{array}{c}32 \\
(8.4 \%)\end{array}$ & 383 \\
\hline B26 & $\begin{array}{l}\text { Tempoh masa } \\
\text { permukiman yang } \\
\text { disyaratkan bagi } \\
\text { membolehkan } \\
\text { pelaksanaan solat jama' } \\
\text { dan qasar bagi mereka } \\
\text { yang tidak pasti bila } \\
\text { urusan akan selesai }\end{array}$ & $\begin{array}{c}116 \\
(31.4 \%)\end{array}$ & $\begin{array}{c}126 \\
(34.1 \%)\end{array}$ & $\begin{array}{c}127 \\
(34.4 \%)\end{array}$ & 369 \\
\hline B23 & $\begin{array}{l}\text { Doktor/jururawat } \\
\text { melakukan solat jama' } \\
\text { kerana terlibat dengan } \\
\text { pembedahan yang } \\
\text { panjang atau urusan } \\
\text { menyelamatkan nyawa } \\
\text { pesakit di hospital }\end{array}$ & $\begin{array}{c}244 \\
(63.5 \%)\end{array}$ & $\begin{array}{c}113 \\
(29.4 \%)\end{array}$ & $\begin{array}{c}27 \\
(7.0 \%)\end{array}$ & 384 \\
\hline
\end{tabular}


Percampuran Mazhab Dalam Isu Ibadat

\begin{tabular}{|c|c|c|c|c|c|}
\hline B36 & $\begin{array}{l}\text { Semasa sembahyang } \\
\text { berjemaah Subuh, } \\
\text { imam terlupa untuk } \\
\text { membaca qunut dan } \\
\text { tidak melakukan sujud } \\
\text { sahwi. }\end{array}$ & $\begin{array}{c}275 \\
(71.2 \%)\end{array}$ & $\begin{array}{c}104 \\
(26.9 \%)\end{array}$ & $\begin{array}{c}7 \\
(1.8 \%)\end{array}$ & $\begin{array}{c}386 \\
(100 \%)\end{array}$ \\
\hline B18 & $\begin{array}{l}\text { Adakah seorang } \\
\text { doktor yang terpaksa } \\
\text { melakukan rawatan } \\
\text { terhadap anjing setiap } \\
\text { hari perlu bersamak } \\
\text { pada semua peralatan } \\
\text { dan pakaiannya? }\end{array}$ & $\begin{array}{c}237 \\
(62.9 \%)\end{array}$ & $\begin{array}{c}98 \\
(26 \%)\end{array}$ & $\begin{array}{c}42 \\
(11.1 \%)\end{array}$ & 377 \\
\hline B17 & $\begin{array}{l}\text { Adakah seseorang } \\
\text { yang telah luka dan } \\
\text { cedera digigit anjing } \\
\text { di seluruh tubuh perlu } \\
\text { bersamak? }\end{array}$ & $\begin{array}{c}254 \\
(67 \%)\end{array}$ & $\begin{array}{c}89 \\
(23.5 \%)\end{array}$ & $\begin{array}{c}34 \\
(9.0 \%)\end{array}$ & 379 \\
\hline $\mathrm{B} 32$ & $\begin{array}{l}\text { Mencabut gigi di bulan } \\
\text { Ramadhan. }\end{array}$ & $\begin{array}{c}300 \\
(78.1 \%)\end{array}$ & $\begin{array}{c}72 \\
(18.8 \%)\end{array}$ & $\begin{array}{c}12 \\
(3.1 \%)\end{array}$ & $\begin{array}{c}384 \\
(100 \%)\end{array}$ \\
\hline B15 & $\begin{array}{l}\text { Adakah wudhu' } \\
\text { terbatal jika seorang } \\
\text { lelaki bersentuhan } \\
\text { kulit dengan wanita } \\
\text { ajnabi? }\end{array}$ & $\begin{array}{c}323 \\
(85.4 \%)\end{array}$ & $\begin{array}{c}54 \\
(14.2 \%)\end{array}$ & $\begin{array}{c}1 \\
(0.3 \%)\end{array}$ & $\begin{array}{c}378 \\
(100 \%)\end{array}$ \\
\hline B20 & $\begin{array}{l}\text { Mengambil wudhu' } \\
\text { dengan menyapu air } \\
\text { di stoking sebagai } \\
\text { ganti membasuh } \\
\text { kaki setelah wudhu' } \\
\text { yang diambil secara } \\
\text { sempurna terbatal. }\end{array}$ & $\begin{array}{c}315 \\
(82.7 \%)\end{array}$ & $\begin{array}{c}48 \\
(12.6 \%)\end{array}$ & $\begin{array}{c}18 \\
(4.7 \%)\end{array}$ & 381 \\
\hline $\mathrm{B} 21$ & $\begin{array}{lrr}\text { Bersolat } & \text { jumaat } \\
\text { di } & \text { masjid } & \text { yang } \\
\text { tidak } & \text { cukup } & 40 \\
\text { orang } & \text { bilangan } \\
\text { pemastautinnya. }\end{array}$ & $\begin{array}{c}339 \\
(87.5 \%)\end{array}$ & $\begin{array}{c}42 \\
(10.9 \%)\end{array}$ & $\begin{array}{c}6 \\
(1.6 \%)\end{array}$ & $\begin{array}{c}387 \\
(100 \%)\end{array}$ \\
\hline $\mathrm{B} 33$ & $\begin{array}{l}\text { Memasukkan } r \text { ubat } \\
\text { kapsul ke dalam } \\
\text { dubur ketika berpuasa } \\
\text { (supositori). }\end{array}$ & $\begin{array}{c}333 \\
(86.0 \%)\end{array}$ & $\begin{array}{c}40 \\
(10.3 \%)\end{array}$ & $\begin{array}{c}14 \\
(3.6 \%)\end{array}$ & 387 \\
\hline B19 & $\begin{array}{lr}\text { Mengambil } & \text { wudhu' } \\
\text { menggunakan } & \text { air } \\
\text { musta'mal } & \end{array}$ & $\begin{array}{c}336 \\
(88 \%)\end{array}$ & $\begin{array}{c}37 \\
(9.6 \%)\end{array}$ & $\begin{array}{c}11 \\
(2.9 \%)\end{array}$ & $\begin{array}{c}384 \\
(100 \%)\end{array}$ \\
\hline
\end{tabular}




\begin{tabular}{|c|l|c|c|c|c|}
\hline B34 & $\begin{array}{l}\text { Meneruskan makan } \\
\text { dan minum sahur } \\
\text { selepas waktu imsak } \\
\text { sebelum azan subuh. }\end{array}$ & $\begin{array}{c}348 \\
(89.7 \%)\end{array}$ & $\begin{array}{c}\mathbf{3 6} \\
\mathbf{( 9 . 3 \% )}\end{array}$ & $\begin{array}{c}4 \\
(1.0 \%)\end{array}$ & $\begin{array}{c}388 \\
(100 \%)\end{array}$ \\
\hline B25 & $\begin{array}{l}\text { Bermusafir selama } \\
\text { tiga hari. Bolehklah } \\
\text { melakukan solat jama' } \\
\text { dan qasar di tempat } \\
\text { yang dituju? }\end{array}$ & $\begin{array}{c}373 \\
(96.9 \%)\end{array}$ & $\begin{array}{c}\mathbf{1 2} \\
\mathbf{( 3 . 1 \% )}\end{array}$ & 0 & $\begin{array}{c}385 \\
(100 \%)\end{array}$ \\
\hline B16 & $\begin{array}{l}\text { Bersentuhan dengan } \\
\text { anjing dalam keadaan } \\
\text { basah. }\end{array}$ & $\begin{array}{c}378 \\
(97.4 \%)\end{array}$ & $\begin{array}{c}\mathbf{6} \\
\mathbf{( 1 . 5 \% )}\end{array}$ & $\begin{array}{c}4 \\
(1.0 \%)\end{array}$ & $\begin{array}{c}388 \\
(100 \%)\end{array}$ \\
\hline
\end{tabular}

Data di atas menunjukkan bahawa masyarakat Islam di Malaysia mengamalkan percampuran mazhab dalam isu-isu ibadat dalam kehidupan mereka. Percampuran mazhab ini bukan hanya terdapat dalam satu aspek ibadat sahaja malah berlaku dalam segenap aspek meliputi taharah, wudhu', solat, puasa dan zakat.

Daripada data di atas, didapati tahap percampuran mazhab dalam amalan masyarakat Malaysia kebanyakannya masih berada di tahap yang rendah. Hanya tiga soalan yang menunjukkan berlakunya percampuran mazhab atau pemilihan jawapan selain mazhab Syafi'i yang tinggi iaitu soalan $37^{11}$, soalan $28^{12}$ dan soalan $41^{13}$.

Dapat disimpulkan bahawa penerimaan masyarakat terhadap percampuran mazhab yang tinggi dalam isu-isu ini adalah disebabkan ia telah menjadi amalan yang diterima masyarakat dan ia merupakan isu yang telah diputuskan dan dikuatkuasakan melalui perundangan. Pemilihan jawapan wang kepada soalan 37 adalah kerana pembayaran zakat fitrah menggunakan wang telah dikuatkuasakan oleh pusat pungutan zakat untuk memudahkan pembayaran. Dalam soalan 28 pula, masyarakat cenderung memilih jawapan sah puasa di hari yang tidak dilafazkan niat itu walaupun bertentangan dengan pandangan mazhab Syafi'i yang mengatakan tidak sah dan perlu berniat puasa setiap hari kerana ia

\footnotetext{
11 Soalan 37 : Anda membayar zakat fitrah dengan?

12 Soalan 28 : Ahmad yang telah berniat puasa sebulan Ramadhan telah te lupa untuk berniat pada hari tertentu pada bulan Ramadhan tersebut. Bagaimanakah puasanya pada hari tertentu tersebut?

13 Soalan 41 : Bagaimanakah cara pembayaran zakat padi dilakukan?
} 
adalah syarat. Ini kerana jawapan yang bersandar kepada mazhab Maliki itu telah menjadi amalan dalam masyarakat secara meluas, malah guru-guru yang bermazhab Syafi' $i$ di institusi pondok juga menganjurkan amalan demikian sebagai langkah ihtiyāt.

Amalan-amalan yang melibatkan percampuran mazhab secara sederhana $(50-79 \%)$ pula merangkumi 7 soalan iaitu soalan $44^{14}$, soalan $40^{15}$, soalan $43^{16}$, soalan $14^{17}$, soalan $13^{18}$, soalan $12^{19}$ dan soalan $31^{20}$.

Masyarakat memilih jawapan selain mazhab Syafi'i dalam soalan-soalan di atas kerana cenderung memilih jawapan yang munasabah untuk mereka amalkan dan yang mudah untuk mengelak masyaqqah (kesusahan) yang terkandung dalam amalan tersebut. Sebagai contoh, soalan 12, 13 dan 14. Dalam soalan 12, sebanyak $39.9 \%$ responden memilih jawapan yang disandarkan kepada mazhab Hanafi iaitu mengambil wudhu' pada anggota yang sihat dan cukup dengan menyapu air disimen sebagai ganti membasuh kaki dan $18.6 \%$ memilih untuk tidak berwudhu' sebaliknya cukup dengan bertayammum sahaja. Begitu juga dengan soalan 13 yang mana responden cenderung untuk memilih jawapan selain Syafi' $i$ iaitu tidak setuju bahawa pesakit perlu berwudhu' dahulu sebelum membalut kakinya dengan belat/plaster/simen. Dalam soalan 14, sebanyak $64.2 \%$ responden memilih tidak wajib qadha' solat yang dilakukan ketika sakit tanpa mengambil wudhu' sebelum memakai belat tersebut sedangkan pandangan mazhab Syafi' $i$ adalah wajib qadha' solat-solat tersebut.

14 Soalan 44 : Adakah anda menolak keperluan asasi (nafkah diri dan keluarga) sebelum membayar zakat?

15 Soalan 40 : Cara pembayaran zakat pendapatan/gaji?

16 Soalan 43 : Cara pembayaran zakat KWSP?

17 Soalan 14 : Adakah pesakit yang solat menggunakan wudhu' tanpa be wudhu' dengan sempurna terlebih dahulu sebelum memakai simen perlu mengqadha' semula solatnya yang ditinggalkan ketika sakit selepas sembuh?

18 Soalan 13 : Adakah pesakit yang disimen kakinya perlu berwudhu' dahulu sebelum memakai simen/belat/ plaster?

19 Soalan 12 : Bagaimana cara berwudhu' bagi pesakit yang disimen kakinya?

20 Soalan 31 : Memasukkan glukos ke dalam badan ketika berpuasa melalui saluran urat/infusi? 
Soalan 40, 43 dan 44 pula menunjukkan tahap percampuran mazhab yang sederhana kerana ia termasuk dalam isu yang telah dikuatkuasakan melalui perundangan walaupun tidak secara meluas di seluruh Malaysia. Cara pembayaran zakat gaji atau pendapatan (soalan 40) menurut Syafi'i adalah berasaskan zakat wang simpanan. Namun, masyarakat cenderung memilih jawapan selain itu iaitu potongan bulanan. Ini mungkin disebabkan cara pembayaran tersebut sudah di kuatkuasakan di negeri-negeri tertentu seperti di Selangor.

Sebahagian besar daripada soalan yang dikemukakan kepada responden masih berada dalam tahap amalan dan penerimaan percampuran mazhab yang rendah. Ini dapat dilihat dalam jadual 11:

Jadual 11 : Tahap amalan dan penerimaan masyarakat terhadap percampuran mazhab

\begin{tabular}{|c|c|}
\hline $\begin{array}{c}\text { Tahap Amalan Dan Penerimaan } \\
\text { Masyarakat Terhadap } \\
\text { Percampuran Mazhab }\end{array}$ & Bilangan Dan Peratusan Soalan \\
\hline Tinggi & $3(11.5 \%)$ \\
\hline Sederhana & $7(27 \%)$ \\
\hline Rendah & $16(61.5 \%)$ \\
\hline JUMLAH & $\mathbf{2 6 ( 1 0 0 \% )}$ \\
\hline
\end{tabular}

Kesimpulan yang dapat dibuat melalui jadual 11 adalah masyarakat Islam di Malaysia masih berpegang dengan amalan bersumberkan mazhab Syafi‘i. 61.5\% daripada soalan yang diajukan menunjukkan jawapan yang bersandarkan mazhab selain Syafi' $i$ mendapat pertusan yang rendah iaitu sekitar $0-49 \%$.

Penerimaan baik masyarakat terhadap amalan percampuran mazhab hanyalah dalam isu yang sudah masyhur dan diamalkan secara meluas dalam masyarakat sahaja iaitu $11.5 \%$ daripada soalan yang dikemukakan. Selebihnya sebanyak $27 \%$ soalan mendapat penerimaan yang sederhana iaitu sekitar $50-79 \%$.

26 soalan yang telah diajukan di atas tidak bertanya secara langsung kepada responden berkenaan penerimaan mereka 
terhadap amalan percampuran mazhab. Tujuan penyelidik berbuat demikian adalah untuk tidak memepengaruhi jawapan yang akan diberikan oleh responden di samping untuk mengumpul data-data berkenaan amalan masyarakat Islam di Malaysia. Namun begitu, terdapat satu soalan yang dirangka untuk mengetahui sebab pemilihan jawapan yang bersandarkan mazhab selain Syafi' $i$ secara langsung daripada responden iaitu soalan $38^{21}$. Jadual 12 adalah analisis jawapan bagi soalan tersebut :

Jadual 12 : Sebab penggunaan wang sebagai ganti beras dalam masalah pembayaran zakat fitrah di kalangan responden bermazhab Syafi‘i.

\begin{tabular}{|l|c|}
\hline \multicolumn{1}{|c|}{ Jawapan } & Kekerapan/Peratusan \\
\hline Amalan masyarakat & $31(8.9 \%)$ \\
\hline Arahan pihak berwajib & $74(21.2 \%)$ \\
\hline Mengikut Mazhab Hanafi & $69(19.8 \%)$ \\
\hline Lebih mudah & $172(49.3 \%)$ \\
\hline Lain-lain & $3(0.9 \%)$ \\
\hline JUMLAH & $\mathbf{3 4 9 ( 1 0 0 \% )}$ \\
\hline
\end{tabular}

Majoriti responden yang bermazhab Syafi'i iaitu seramai 49.3\% memilih untuk berpindah mazhab menggunakan wang bagi pembayaran zakat fitrah menggantikan beras kerana berpendapat cara tersebut lebih mudah untuk dilakukan. Seterusnya, pembayaran zakat fitrah dilakukan dengan menyalahi pandangan mazhab Syafi'i ini juga dilakukan kerana ia merupakan arahan pihak berwajib yang mewakili $21.2 \%$. Hanya $19.8 \%$ responden sahaja yang beralasan membayar zakat fitrah dengan menggunakan wang kerana mengikut mazhab Hanafi dan selebihnya $8.9 \%$ mengatakan kerana ia adalah amalan masyarakat.

Daripada analisis di atas, dapat dibuat kesimpulan secara ringkas bahawa masyarakat Islam di Malaysia lebih cenderung untuk melakukan percampuran mazhab dan berpindah kepada mazhab yang lebih mudah jika terdapat masyaqqah atau kesusahan dalam pelaksanaan amalan asal tersebut. Alasan ini lebih diterima oleh

21 Soalan 38 : Mengapa anda memilih untuk membayar zakat fitrah dengan wang? 
ramai responden bernazhab Syafi'i berbanding alasan mengikut amalan mazhab lain.

\section{KESIMPULAN}

Majoriti masyarakat Malaysia mengaku berpegang dengan mazhab Syafi'i. Namun begitu, dari segi amalan, mereka tidak mengikut dan mengamalkan pandangan mazhab Syafi'i secara sepenuhnya. Berlaku perpindahan dan pengambilan pandangan mazhab lain dalam sesetengah perkara seperti dalam isu taharah, wudhu', solat, puasa dan zakat. Perpindahan dan percampuran mazhab tersebut dikesan berlaku secara meluas dalam sesetengah persoalan dalam isu-isu tersebut dan secara sederhana atau rendah dalam setengah persoalan yang lain. Perpindahan mazhab berlaku dengan meluas di kalangan masyarakat dalam perkara-perkara berikut :

1. Perkara-perkarayangmengandungimasyaqqahataukesusahan dalam pengamalannya. Dalam hal tersebut, masyarakat cenderung untuk memilih pendapat yang dirasakan mudah dan munasabah untuk dilakukan.

2. Perkara yang telah telah diputuskan oleh badan berkuasa dan telah dikuatkuasakan melalui perundangan. Dalam situasi ini, masyarakat akan menerima dan mengamalkan perkara tersebut walaupun ia bukan merupakan pandangan mazhab Syafi'i.

3. Perkara yang telah diterima sekian lama dan menjadi amalan meluas dalam masyarakat. Masyarakat hanya mengikut sahaja amalan tersebut walaupun ia bukan berasaskan pandangan mazhab Syafi‘i.

Percampuran mazhab atau kecenderungan untuk memilih pandangan mazhab selain Syafi'i kurang berlaku dalam isuisu yang telah diketahui secara meluas dalam masyarakat. Walaubagaimanapun, melalui kajian didapati berlaku peningkatan kecenderungan dalam memilih pandangan mazhab selain Syafi' $i$ dalam persoalan-persoalan yang kurang biasa dipelajari secara meluas dan tidak biasa dihadapi oleh masyarakat. 